\title{
Residence times and mixing of water in river banks: implications for recharge and groundwater-surface water exchange
}

\author{
N. P. Unland ${ }^{1,2}$, I. Cartwright ${ }^{1,2}$, D. I. Cendón ${ }^{3,4}$, and R. Chisari ${ }^{3}$ \\ ${ }^{1}$ School of Earth, Atmosphere and Environment, Monash University, Clayton, Vic 3800, Australia \\ ${ }^{2}$ National Centre for Groundwater Research and Training, School of Environment, Flinders University, Adelaide, \\ SA 5001, Australia \\ ${ }^{3}$ Australian Nuclear Science and Technology Organisation, Kirrawee DC, NSW 2232, Australia \\ ${ }^{4}$ School of Biology, Earth and Environmental Sciences, University of New South Wales, Sydney, NSW 2052, Australia \\ Correspondence to: N. P. Unland (nicolaas.unland@gmail.com)
}

Received: 15 January 2014 - Published in Hydrol. Earth Syst. Sci. Discuss.: 7 February 2014

Revised: 18 September 2014 - Accepted: 20 September 2014 - Published: 12 December 2014

\begin{abstract}
Bank exchange processes within $50 \mathrm{~m}$ of the Tambo River, southeast Australia, have been investigated through the combined use of ${ }^{3} \mathrm{H}$ and ${ }^{14} \mathrm{C}$. Groundwater residence times increase towards the Tambo River, which suggests the absence of significant bank storage. Major ion concentrations and $\delta^{2} \mathrm{H}$ and $\delta^{18} \mathrm{O}$ values of bank water also indicate that bank infiltration does not significantly impact groundwater chemistry under baseflow and post-flood conditions, suggesting that the gaining nature of the river may be driving the return of bank storage water back into the Tambo River within days of peak flood conditions. The covariance between ${ }^{3} \mathrm{H}$ and ${ }^{14} \mathrm{C}$ indicates the leakage and mixing between old ( $\sim 17200$ years) groundwater from a semiconfined aquifer and younger groundwater $(<100$ years) near the river, where confining layers are less prevalent. It is likely that the upward infiltration of deeper groundwater from the semi-confined aquifer during flooding limits bank infiltration. Furthermore, the more saline deeper groundwater likely controls the geochemistry of water in the river bank, minimising the chemical impact that bank infiltration has in this setting. These processes, coupled with the strongly gaining nature of the Tambo River are likely to be the factors reducing the chemical impact of bank storage in this setting. This study illustrates the complex nature of river groundwater interactions and the potential downfall in assuming simple or idealised conditions when conducting hydrogeological studies.
\end{abstract}

\section{Introduction}

Documenting water balances in river systems is vitally important to understanding hydrological processes and protecting and managing water resources. While surface run-off and regional groundwater inflows are the two main components of river flow, river banks may act as sites of transient water storage. Bank storage represents water that infiltrates into alluvial aquifers at high river stage and subsequently returns to the river as the river stage declines (e.g. Chen and Chen, 2003; McCallum et al., 2010; Singh, 1968; Winter et al., 1998). Bank storage is an important hydrological process that may considerably reduce peak river discharge during floods and maintain river discharge during periods of decreased rainfall (Pinder and Sauer, 1971). In addition, bank waters may represent a source of nutrients or contaminants derived from the river that are gradually released following diminishing of the flood peak. The volume and duration of bank storage for a given river stretch will depend on the flood peak height and the flood duration (Cooper and Rorabaugh, 1963), as well as the hydraulic conductivity of the alluvial aquifer and the hydraulic gradient between the aquifer and river (Cartwright et al., 2014; Chen et al., 2006; McCallum et al., 2010). Whiting and Pomeranets (1997) showed that deeply incised narrow rivers with wider floodplains and coarse alluvial material have greater bank storage potential. The potential for significant storage beneath the streambed was identified by Chen and Chen (2003), while Chen et al. (2006) showed that bank storage will return more rapidly 
in gaining river sections. Bank slope has also been shown to impact bank storage, with shallower bank slope providing a greater potential for bank storage (Doble et al., 2012).

The concentrations of solutes in river water are commonly lower than those in groundwater, and mixing between infiltrating river water and groundwater may produce zones of lower solute concentrations in river banks. McCallum et al. (2010) showed that solute concentrations of bank water may take months to return to their original concentration. During that time period, the water that flows from the banks into the river is a mixture of regional groundwater and bank storage waters. This suggests that there may be a component of bank storage waters in river banks with a residence time of months to years. Recognising that bank storage waters may contribute to rivers over long time frames is important for estimating groundwater discharge by chemical mass balance. If the bank storage waters are chemically similar to surface water rather than regional groundwater, using the composition of regional groundwater as an endmember will result in underestimation of the groundwater flux (Cartwright et al., 2014; McCallum et al., 2010; Unland et al., 2013).

While the concept of bank storage is well understood, accurately quantifying the volume of water that infiltrates the banks and the duration of bank return flows remains difficult. Many studies have focused on using analytical and numerical solutions to understand bank storage from variations in the river hydrograph and groundwater heads. Most of these studies have concluded that bank storage periods will significantly exceed the duration of flood events. Typically bank storage return to the river is proposed to decrease exponentially after flood events, and in the case of sandy river banks with wide floodplains, residence times can be of the order of years (Doble et al., 2012; McCallum et al., 2010; Whiting and Pomeranets, 1997). These studies commonly assume ideal or generalised conditions such as aquifer homogeneity, vertical river banks and saturated conditions (Doble et al., 2012), making them difficult to apply to many natural settings. Therefore, there is a need to document the extent and timescales of bank storage in specific catchments.

Geochemical processes occurring within river banks, such as the bacterial degradation of organic matter or the weathering of minerals, can influence the concentrations of DOC, $\mathrm{O}_{2}, \mathrm{NO}_{3}, \mathrm{Na}, \mathrm{K}$ and other major ions in near-river groundwater (Bourg and Bertin, 1993). Fukada et al. (2003) identified the continuing denitrification of river water as it infiltrated an alluvial aquifer and demonstrated that the chemistry of infiltrating water is likely to vary according to its residence time within the alluvial aquifer. Understanding the source and load of nutrients in rivers is fundamental in understanding their ecology (Boulton, 1993, 2005), while determining the different sources of water in the riparian zone is crucial to effective vegetation management (Cey et al., 1999; Lambs, 2004; Lamontagne et al., 2005; Woessner, 2000). Similarly, the impact of infiltrating river water on water quality in alluvial aquifers is important when developing groundwater extraction systems for water supply (Hiscock and Grischek, 2002).

It is important to carry out studies of bank storage in a range of environments as variations in climate and river form translate into variations in river regime (e.g. frequency and duration of floods) that may cause differences in bank infiltration. Field studies focussed on bank storage and the dating of bank water in Australian catchments has been limited. Lamontagne et al. (2011) and Cendón et al. (2010) indicated the presence of relatively young $(<50$ years) groundwater in river banks, and Cartwright et al. (2010) showed that preferential floodplain recharge is likely to occur near rivers during flooding. In contrast, groundwater in upland catchments in Australia has been shown to have relatively long residence times (Atkinson et al., 2013). This study investigates bank storage processes in the Tambo River catchment, Victoria, Australia. The objectives of the study are to use the geochemistry of groundwater in the banks of the Tambo River at different discharges in order to (1) define the major processes controlling the chemistry of water stored in river banks, (2) determine the age and likely sources water stored in river banks and (3) identify the factors controlling bank storage and the distance over which bank storage is occurring. While this study uses data from specific field area, the Tambo River is similar to many others globally, and the results will help in understanding bank storage processes in general.

\subsection{Study area}

Investigations took place on the middle reaches of the Tambo River in southeast Australia. The Tambo River is perennial and flows through forest and woodland, with cattle grazing on the river floodplains (Department of Agriculture, Fisheries and Forestry, 2006). It discharges into the saline Lake King, and the lower $\sim 15 \mathrm{~km}$ of the river is estuarine. Average annual precipitation in the catchment increases from $655 \mathrm{~mm}$ in the upper reaches to $777 \mathrm{~mm}$ in the middle and lower reaches (Bureau of Meteorology, 2013). During the majority of the study period, the discharge of the Tambo River ranged from $10^{10}$ to $10^{11} \mathrm{~m}^{3} \mathrm{~s}^{-1}$ (Victorian Water Resources Data Warehouse, 2013); however significant rainfall during August 2011 and March 2012 resulted in discharge events that peaked at greater than $5 \times 10^{12} \mathrm{~m}^{3} \mathrm{~s}^{-1}$ (Fig. 2).

The upper catchment of the Tambo River drains indurated Ordovician and Devonian turbidites and granites of the Eastern Victorian Uplands, while the lower and middle catchment is in the Gippsland Basin (Birch, 2003). The near-river sediments in the lower and middle catchment comprise coarse Quaternary alluvial gravels and sands. These recent alluvial sediments overlie the Plio-Pleistocene Haunted Hill Gravels, which represents the shallowest regional-scale aquifer in the Gippsland Basin. Clay layers throughout the Quaternary alluvium and Haunted Hill Gravels act as aquitards, separating a number of aquifer horizons that range from unconfined 


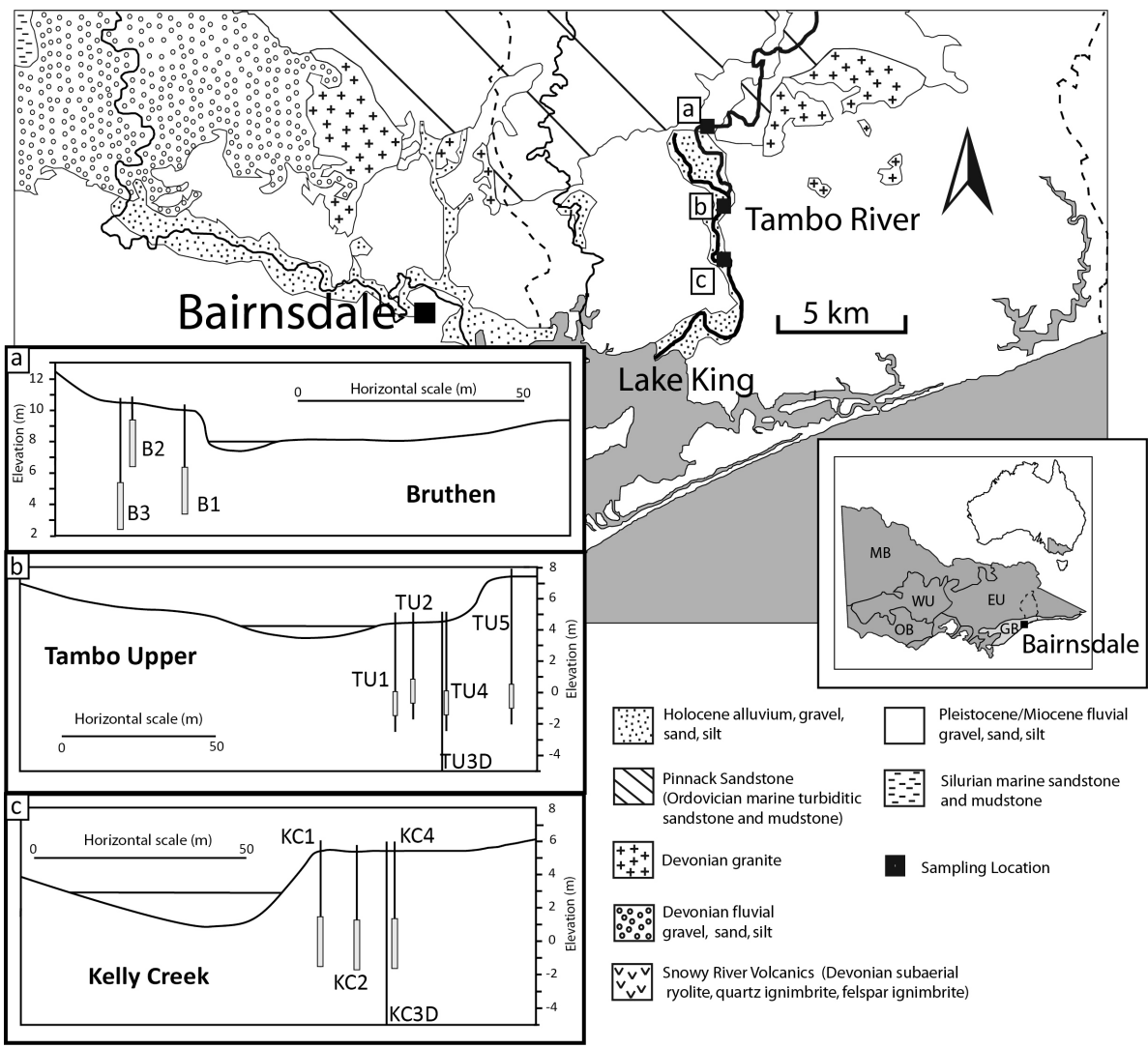

Figure 1. Location of field area and schematic cross sections of bore transects at Bruthen (a), Tambo Upper (b) and Kelly Creek (c). Screened sections indicated by open boxes. Dashed line represents Tambo River basin boundary (transects orientated facing upstream).

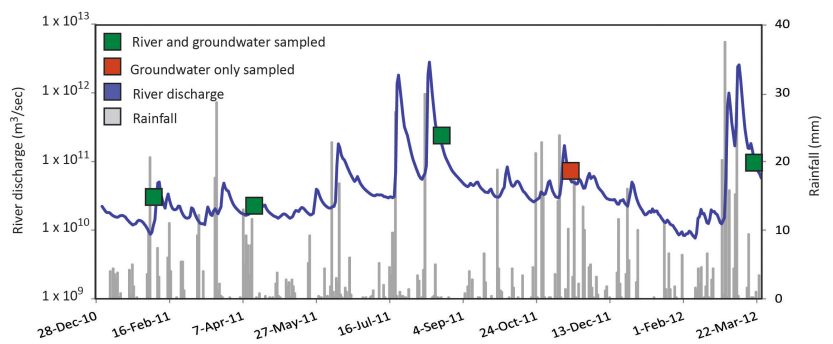

Figure 2. Surface and groundwater sampling frequency superimposed on Tambo River hydrograph (Battens Landing, station 223209 - Water Resources Data Warehouse, 2013) and rainfall (Bairnsdale Airport, station 85279 - Bureau of Meteorology, 2013).

to fully confined (Hocking, 1976). Deeper aquifer systems in the lower Tambo catchment include the late Miocene to early Pliocene Boisdale Formation and the Oligocene to Pliocene Jemmy's Point, Tambo River and Lake Wellington formations (Leonard, 1992; Birch, 2003; Hofmann and Cartwright, 2013). These deeper aquifer systems are separated from the near-surface sediments by clay layers that locally form aquitards. Regional groundwater flow in all aquifers is from the margins of the Gippsland Basin towards Lake King
(Southern Rural Water, 2013). Overall, the lower and middle reaches of the Tambo River are gaining, especially at low river discharge when hydraulic gradients in the shallow alluvial sediments are towards the river (Unland et al., 2013). The regional groundwater from the deeper aquifers is artesian and head gradients around Lake King (Fig. 1) are upwards (Victorian Water Resources Data Warehouse, 2013; Southern Rural Water, 2013). The regional groundwater also has a high salinity (total dissolved solids up to $20000 \mathrm{mg} \mathrm{L}^{-1}$ ), is generally anoxic and has a significantly higher temperature (up to $40^{\circ} \mathrm{C}$ ) than that of the shallow groundwater. Springs fed by this deeper groundwater are recorded around Lake King; however, these are rare elsewhere (although, as discussed below, the regional groundwater may mix with the shallow groundwater and river water in the banks at Tambo Upper, Fig. 1). Most groundwater that discharges into the middle reaches of the Tambo River is most likely derived from the shallower aquifers (Southern Rural Water, 2013), and the flow is part of a local rather than regional system (cf. Tóth, 1963). This is consistent with the presence of clays in the Gippsland Basin sediments that produce a compartmentalised aquifer system. 


\subsection{Study sites}

Transects of groundwater monitoring bores were set up at three locations on the river banks of the middle Tambo River (Fig. 1, Tables 1, 2 and 3). The transect at Bruthen is $28.5 \mathrm{~km}$ upstream of Lake King and consists of three bores installed at 5.5, 17.6 and $18.3 \mathrm{~m}$ distance from the river and 8.0, 5.4 and $7.1 \mathrm{~m}$ depth below ground surface, respectively (Fig. 1). The transect at Tambo Upper, $20.2 \mathrm{~km}$ upstream of Lake King, consists of five bores installed at 8.8, 15.0, 22.3, 23.8 and $37.9 \mathrm{~m}$ distance from the Tambo River and 6.7, 6.2, 23.1, 6.7 and $9.8 \mathrm{~m}$ depth below ground surface, respectively. The final transect at Kelly Creek, $13.8 \mathrm{~km}$ upstream of Lake King, consists of four bores installed at 7.0, 17.9, 24.9 and $26.8 \mathrm{~m}$ from the Tambo River at depths of 8.1, 7.8, 28 and $7.9 \mathrm{~m}$ depth, respectively. Bores at Tambo Upper have $1.5 \mathrm{~m}$ screens starting $1 \mathrm{~m}$ from the borehole bottom, while all other installations have a $3 \mathrm{~m}$ screened section set at the bottom of the borehole. Sediment samples taken during installation of the shallower $(<15 \mathrm{~m}$ deep) bores via auger drilling indicate that the alluvial aquifer at all transects is dominated by coarse sands with 10 to $20 \mathrm{~cm}$ thick clay layers dispersed throughout. Deeper bores were constructed via mud rotary drilling, which tends to preferentially return coarser sediment fractions. While clay layers are harder to identify, the groundwater at $>20 \mathrm{~m}$ depth is artesian (see below), which suggests the presence of a clay-rich confining layer. All bores are screened in the alluvial sands/gravels and (except for the deeper bore at Tambo Upper) probably sample the local shallow groundwater rather than the deeper regional groundwater.

\section{Methods}

Bore and river elevations were determined to $\pm 1 \mathrm{~cm}$ relative to the Australian Height Datum (AHD) using a Trimble digital global positioning system (DGPS). Bores were sampled using an impeller pump set at the screened section, and at least three bores' volumes were pumped before sample collection. Five sets of groundwater samples and four sets of river samples were collected between February 2011 and March 2012 at each transect. Sampling during February 2011, April 2011 and November 2011 took place at conditions close to baseflow, while sampling during August 2011 and March 2012 took place $\sim 1$ week after significant flooding in the catchment (Fig. 2). Rising head slug tests were conducted by pumping bores for $\sim 10 \mathrm{~min}$ with an impeller pump at a rate of $4 \mathrm{~L} \mathrm{~min}^{-1}$ and then allowing groundwater heads to recover. Changes to groundwater levels were recorded using a Rugged TROLL 200 logger logging at $1 \mathrm{~s}$ intervals. Hydraulic conductivity was calculated using the Hvorslev method outlined by Fetter (1994). The anisotropy ratio of the sediments was not taken into account as it is not explicitly known and the aim was to provide a general characterisation of the hydraulic properties of the sediments.

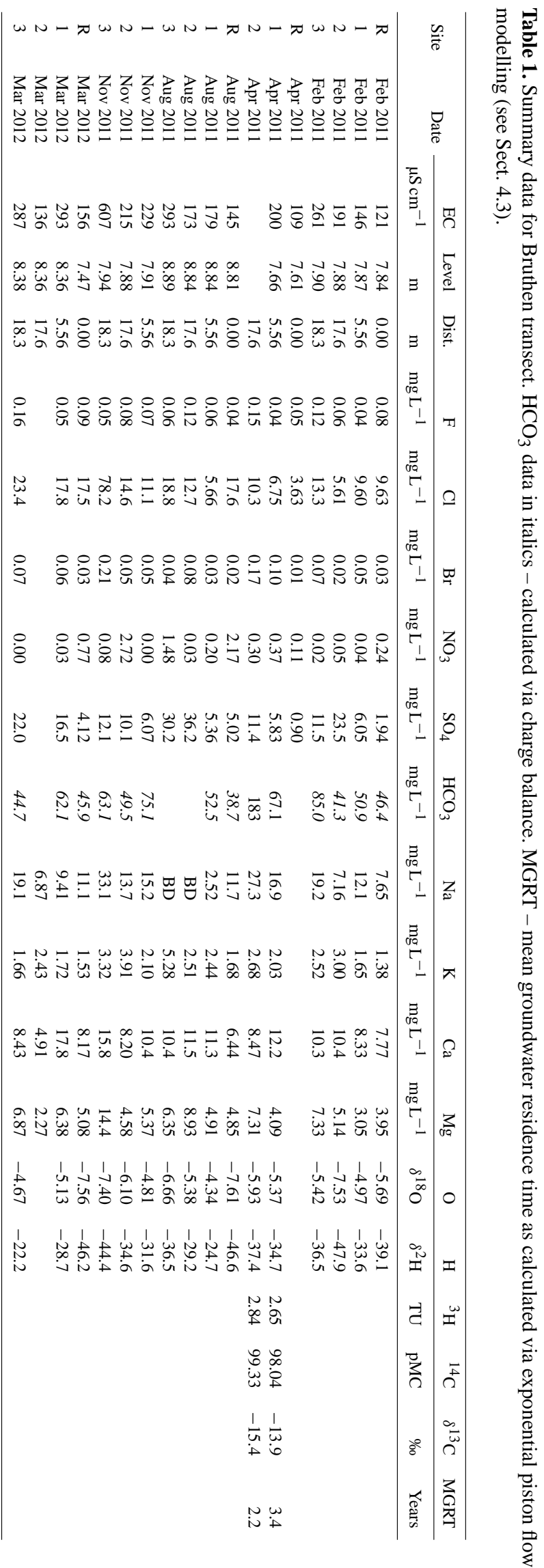

www.hydrol-earth-syst-sci.net/18/5109/2014/ 


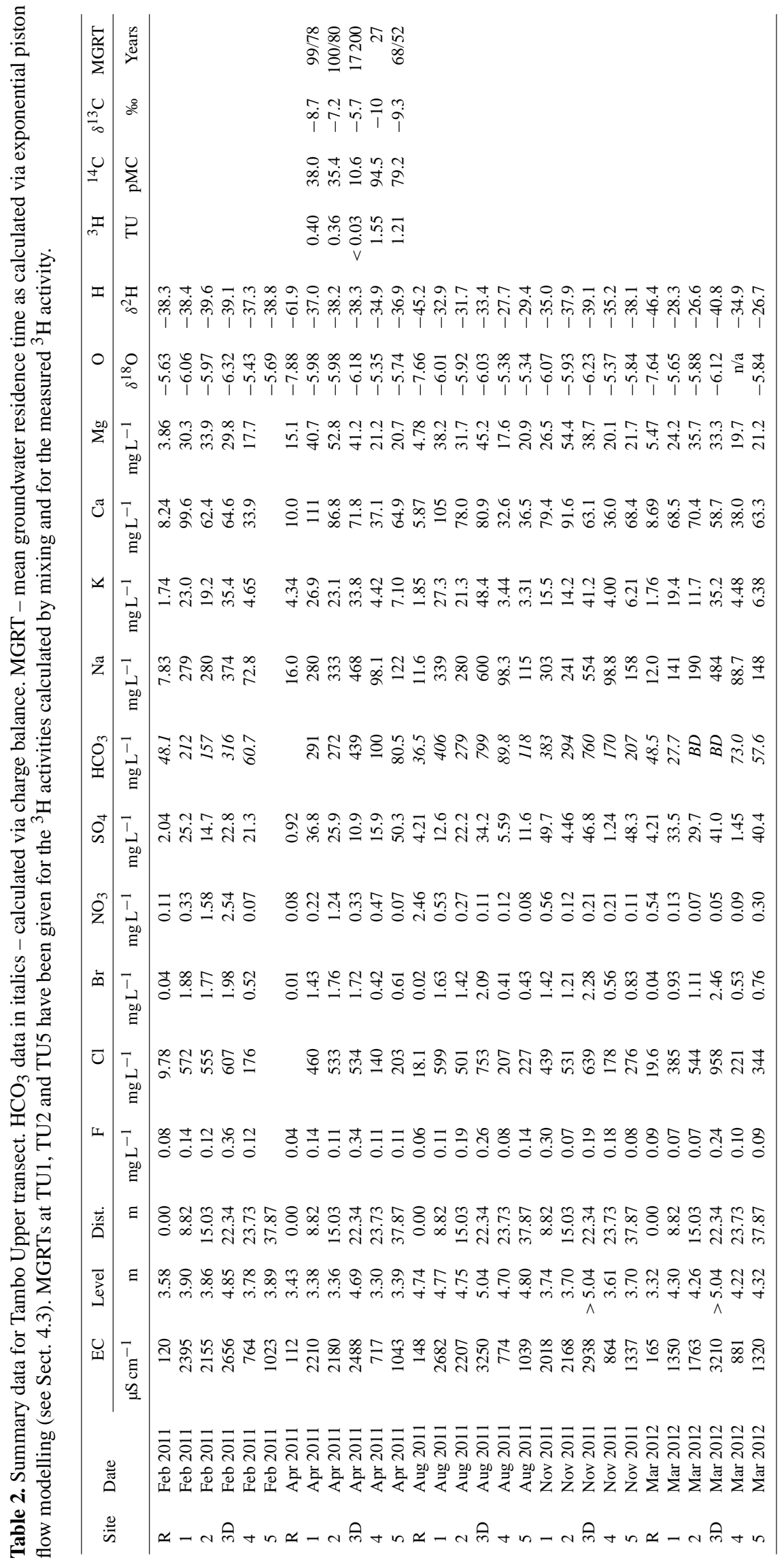




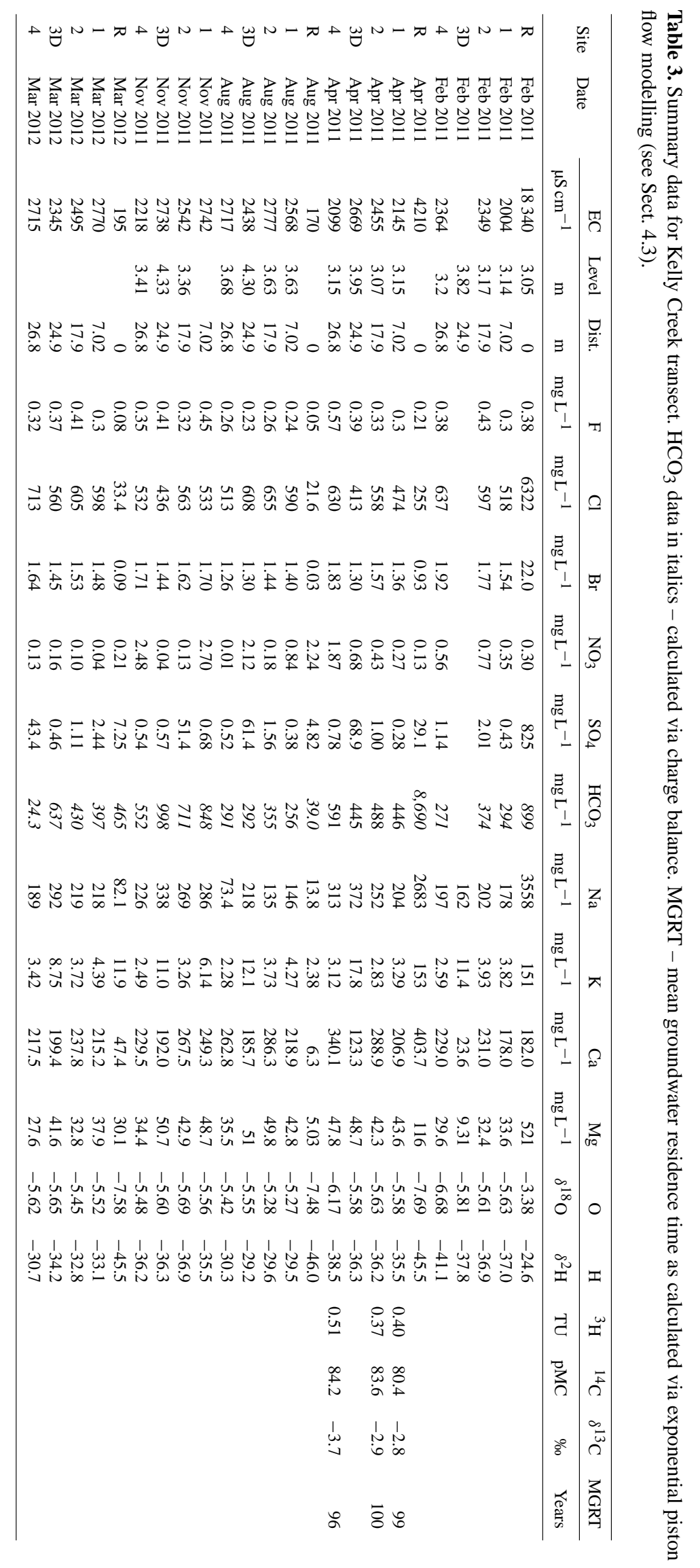


Commonly, the recovery time was $<10 \mathrm{~s}$, and the estimated hydraulic conductivities are likely to be minimum values.

Electrical conductivity (EC) was measured in field to $\pm 1 \%$ using a calibrated TPS $\mathrm{pH} / \mathrm{EC}$ meter, and groundwater levels were measured using an electronic water level tape. Water samples were preserved by refrigeration in airtight polyethylene bottles. $\mathrm{HCO}_{3}$ and dissolved $\mathrm{CO}_{2}$ were measured within $48 \mathrm{~h}$ of sample collection by titration using a Hach digital titrator and reagents with a precision of $\pm 5 \%$. Anion concentrations were determined on filtered $(0.45 \mu$ cellulose nitrate filters) samples using a Metrohm ion chromatograph at Monash University, Clayton, with a precision of $\pm 2 \%$ estimated by replicate analysis. Cation concentrations were determined on samples that were filtered and acidified to $\mathrm{pH}<2$ using twice-distilled $16 \mathrm{M}$ nitric acid by the Varian Vista ICP-AES at the Australian National University or the ThermoFinnigan $\mathrm{X}$ series II, quadrupole ICP-MS at Monash University. Drift during ICP-MS analysis was corrected using internal $\mathrm{Sc}, \mathrm{Y}, \mathrm{In}$ and $\mathrm{Bi}$ standards, with replicate analysis returning a precision of $\pm 5 \%$. Stable isotope ratios were measured at Monash University using ThermoFinnigan MAT 252 and DeltaPlus Advantage mass spectrometers. $\delta^{18} \mathrm{O}$ values of water were measured via equilibration with $\mathrm{He}-\mathrm{CO}_{2}$ at $32{ }^{\circ} \mathrm{C}$ for $24-48 \mathrm{~h}$ in a ThermoFinnigan Gas Bench. $\delta^{2} \mathrm{H}$ values of water were measured via reaction with $\mathrm{Cr}$ at $850^{\circ} \mathrm{C}$ using a Finnigan MAT H/Device. $\delta^{18} \mathrm{O}$ and $\delta^{2} \mathrm{H}$ values were measured relative to internal standards that were calibrated using International Atomic Energy Agency (IAEA) SMOW (Standard mean ocean water), GISP (Greenland ice sheet precipitation) and SLAP (Standard light antarctic precipitation) standards. Data were normalised following Coplen (1988) and are expressed relative to V-SMOW, where $\delta^{18} \mathrm{O}$ and $\delta^{2} \mathrm{H}$ values of SLAP are -55.5 and $-428 \%$, respectively. The precision $(1 \sigma)$ of the analyses based on replicate analyses is $\delta^{18} \mathrm{O}= \pm 0.2 \%$ and $\delta^{2} \mathrm{H}$ $= \pm 1 \%$.

Samples for ${ }^{14} \mathrm{C}$ and ${ }^{3} \mathrm{H}$ analysis were collected during the April 2011 sampling period (Fig. 2). ${ }^{3} \mathrm{H}$ water samples were distilled and electrolytically enriched prior to analysis by liquid scintillation (Morgenstern and Taylor, 2009). The ${ }^{3} \mathrm{H}$ concentrations were expressed in tritium units (TU), with uncertainties ranging from $\sim 25 \%$ at the quantification limit $(0.13 \mathrm{TU})$ to $<6 \%$ for ${ }^{3} \mathrm{H}$ concentrations above 1.5 TU. For ${ }^{14} \mathrm{C}$ analysis, the total DIC (dissolved organic carbon) was converted to $\mathrm{CO}_{2}$ by acidifying the samples with $\mathrm{H}_{3} \mathrm{PO}_{4}$ and extracting the liberated $\mathrm{CO}_{2}$ gas using a custombuilt extraction line. The $\mathrm{CO}_{2}$ sample was then heated in a sealed glass tube containing baked $\mathrm{CuO}$ and $\mathrm{Ag}$ and $\mathrm{Cu}$ wire at $600^{\circ} \mathrm{C}$ for $2 \mathrm{~h}$ to remove any sulfur compounds that may have been liberated and subsequently graphitised. The graphite targets were analysed using the STAR (Small Tandem for Applied Research) AMS (accelerator mass spectrometry) at ANSTO (Australian Nuclear Science and Technology Organisation) following Fink et al. (2004). The activity of ${ }^{14} \mathrm{C}$ is expressed as percent modern carbon (pMC)
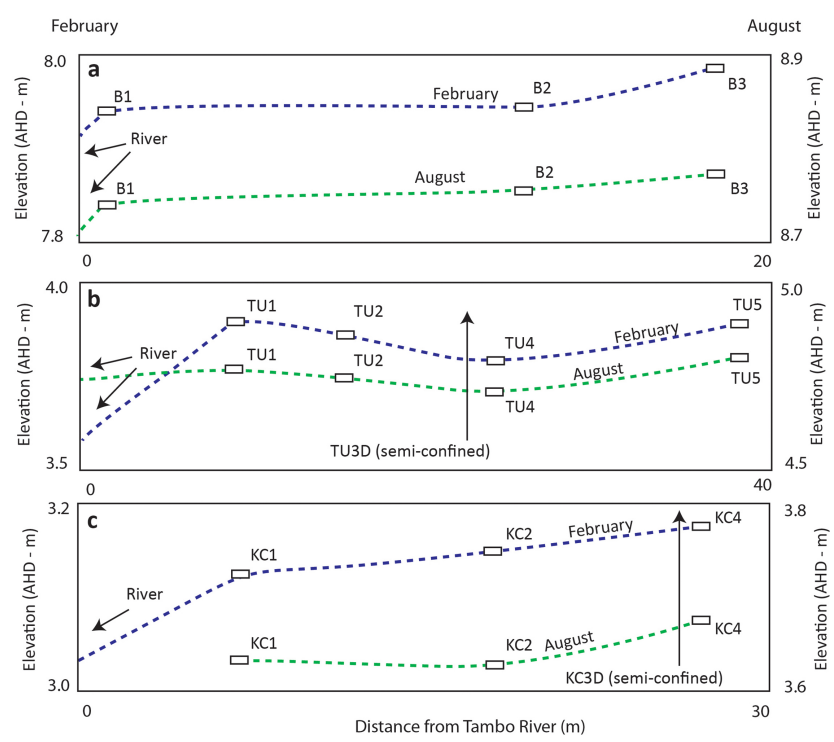

Figure 3. Groundwater elevations during February 2011 and August 2011 at Bruthen (a), Tambo Upper (b) and Kelly Creek (c). White rectangles - measured elevation; dashed lines - interpolated elevations.

following Stuiver and Polach (1977). The average error associated with radiocarbon measurements is $0.3 \%$.

\section{Results}

\subsection{Groundwater elevations and hydraulic conductivities}

Groundwater elevation at Bruthen varied between 7.45 m AHD in April 2011 and 8.89 m AHD in August 2011. There was less than $6 \mathrm{~cm}$ difference in elevations across the transect during any given sampling period. Groundwater elevations in $\mathrm{B} 1$ and $\mathrm{B} 2$ were within $3 \mathrm{~cm}$ of each other during all sampling periods, while elevations in B3 were 2 to $6 \mathrm{~cm}$ higher than in B1 and B2 (Fig. 3). Groundwater elevations at Bruthen were 3 to $4 \mathrm{~cm}$ higher than river elevations during all sampling periods except during March 2012, when groundwater levels were approximately $90 \mathrm{~cm}$ higher than the river elevation. Rising head slug tests at this transect indicate a hydraulic conductivity of $\sim 8.5 \times 10^{-3} \mathrm{~m} \mathrm{~s}^{-1}$.

Groundwater elevation in the shallow bores at Tambo Upper ranged from $3.30 \mathrm{~m}$ AHD in April 2011 to $4.80 \mathrm{~m}$ AHD in August 2011. Groundwater elevations in TU5, TU2 and TU1 in individual campaigns were within 3 to $5 \mathrm{~cm}$ of each other. Groundwater elevations in TU4 were the lowest in the transect, averaging $3.92 \mathrm{~m}$ AHD over the study, approximately $9 \mathrm{~cm}$ lower than the average levels in TU1, TU2 and TU5 (Fig. 3). The deeper bore (TU3D) was artesian during all sampling periods; this bore samples a deeper, semi-confined aquifer within the alluvial gravel that has higher heads than the surficial aquifer. During February 
and April 2011, groundwater elevations in this bore were $4.85 \mathrm{~m}$ and $4.69 \mathrm{~m} \mathrm{AHD}$, respectively, while in all other sampling periods the elevation exceeded that of the casing (5.04 m AHD). Groundwater elevations at Tambo Upper were higher than the river elevation during all periods except April 2011. Groundwater elevation closest to the river (TU1) was $32 \mathrm{~cm}$ higher than river elevation in February 2011, $5 \mathrm{~cm}$ lower then river water during April 2011, $3 \mathrm{~cm}$ higher than river elevation during August 2011 and $99 \mathrm{~cm}$ greater than river elevation during March 2012. Slug tests at this transect yielded hydraulic conductivities ranging from $5.1 \times 10^{-4}$ to $8.6 \times 10^{-5} \mathrm{~m} \mathrm{~s}^{-1}$ in the surficial aquifer and $1.9 \times 10^{-5} \mathrm{~m} \mathrm{~s}^{-1}$ in the semi-confined aquifer.

At Kelly Creek, groundwater levels in the shallower bores ranged from $3.07 \mathrm{~m}$ AHD in April 2011 to $3.68 \mathrm{~m}$ AHD in August 2011 (Fig. 3). Groundwater levels in these bores generally decreased with proximity to the river during all sample periods except April 2011. Groundwater levels in the deeper bore at Kelly Creek (KC3D) were higher than the shallow bores, ranging from $3.82 \mathrm{~m}$ AHD in February 2011 to $4.33 \mathrm{~m}$ AHD in November 2011. Slug tests at this transect indicate hydraulic conductivities ranging from 2.4 to $3.4 \times 10^{-5} \mathrm{~m} \mathrm{~s}^{-1}$.

\subsection{Electrical conductivity}

Groundwater EC values at Bruthen ranged from 136 to $607 \mu \mathrm{sm}^{-1}$. Groundwater at B3 was generally the most saline, ranging from 261 to $607 \mu \mathrm{S} \mathrm{cm}^{-1}$, while that from B1 ranged from 136 to $293 \mu \mathrm{S} \mathrm{cm}^{-1}$. Shallow groundwater at Tambo Upper was more saline than that from Bruthen, ranging from 717 to $2682 \mu \mathrm{S} \mathrm{cm}^{-1}$. Shallow groundwater at Tambo Upper was also generally more saline closer to the river than further from the river, averaging $2110 \mu \mathrm{S} \mathrm{cm}^{-1}$ at TU1 and TU2 over the study period, compared to $980 \mu \mathrm{S} \mathrm{cm}^{-1}$ at TU4 and TU5. Deeper groundwater at Tambo Upper was consistently the most saline in the transect, ranging from $2490 \mu \mathrm{S} \mathrm{cm}^{-1}$ in April 2011 to $3250 \mu \mathrm{S} \mathrm{cm}^{-1}$ in August 2011. Groundwater at Kelly Creek was generally more saline than Tambo Upper, with EC values ranging from 2000 to $2777 \mu \mathrm{S} \mathrm{cm}^{-1}$ over the study period. Groundwater EC values were less variable at Kelly Creek and did not generally increase or decrease with proximity to the Tambo River.

\subsection{Stable isotopes}

$\delta^{18} \mathrm{O}$ and $\delta^{2} \mathrm{H}$ values of groundwater and river water generally plot close to the both local (LMWL) and global meteoric water lines (GMWL); however river water at Kelly Creek from February 2011 plots to the right of the GMWL (Fig. 4). Groundwater and surface water samples from February 2011 define an array with a slightly shallower trend than the LMWL, while those from March 2012 define an array with a steeper trend than the LMWL. $\delta^{18} \mathrm{O}$ values at Bruthen ranged

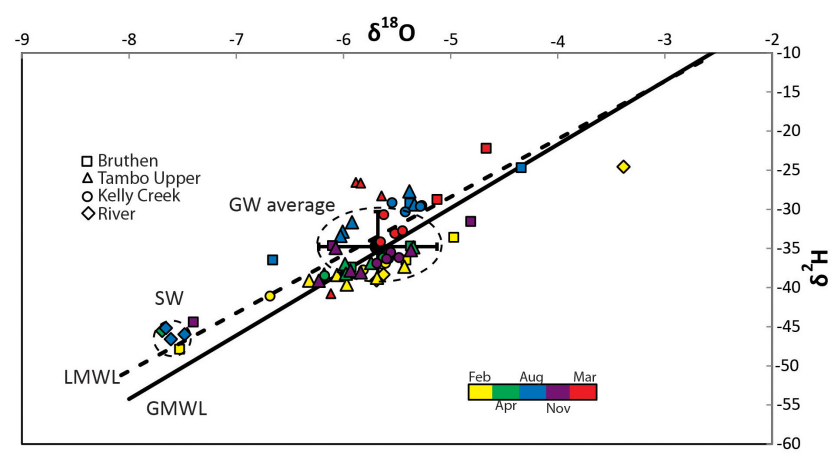

Figure 4. $\delta^{18} \mathrm{O}$ and $\delta^{2} \mathrm{H}$ values of bank water and river water from the Tambo River. LMWL defined by Melbourne meteoric water line in Hughes and Crawford (2012). Dashed lines indicate typical river water and bank water values.

from -4.3 to $-7.5 \%$ and were generally higher closer to the river at $\mathrm{B} 1$ (average $=-4.8 \pm 0.4 \%$ ) than further from the river at $\mathrm{B} 2$ and $\mathrm{B} 3$ (average $=-5.3 \pm 2.2 \%$ ). Stable isotope values were less variable at Tambo Upper, with $\delta^{18} \mathrm{O}$ values ranging from -5.3 to $-6.3 \%$. Groundwater at TU3D, TU1 and TU2 has lower $\delta^{18} \mathrm{O}$ values (average $=-6.0 \pm 0.2 \%$ ) than at TU4 and TU5 (average $=-5.6 \pm 0.2 \%$ ). Shallow groundwater at Kelly Creek showed little variability, with $\delta^{18} \mathrm{O}$ values ranging from -5.3 to $-5.8 \%$ during the study. The deeper groundwater at Kelly Creek had slightly lower $\delta^{18} \mathrm{O}$ values (average $=-5.9 \pm 0.5 \%$ ) than the shallow groundwater. River water had lower $\delta^{18} \mathrm{O}$ values than groundwater during all sampling periods except February 2011. During this period, $\delta^{18} \mathrm{O}$ values of river water increased from $-5.7 \%$ at Bruthen to $-3.4 \%$ at Kelly Creek. There was less variation in the river water at other times during the study, with $\delta^{18} \mathrm{O}$ values ranging from -7.9 to $-7.5 \%$.

\section{$3.4{ }^{3} \mathrm{H}$ and ${ }^{14} \mathrm{C}$}

${ }^{3} \mathrm{H}$ and ${ }^{14} \mathrm{C}$ activities in April 2011 were the highest in groundwater from Bruthen, ranging from 2.7 to 2.8 tritium units and 98.0 to $99.3 \mathrm{pMC}$, respectively. ${ }^{3} \mathrm{H}$ activities were higher in groundwater further from the river at Tambo Upper at TU4 and TU5 $\left({ }^{3} \mathrm{H}\right.$ activities of 1.6 and 1.2 tritium units, respectively) compared to groundwater closer to the river at TU1 and TU2 $\left({ }^{3} \mathrm{H}\right.$ activities of 0.40 and 0.36 tritium units, respectively). ${ }^{3} \mathrm{H}$ activities in the deeper groundwater at TU3D were below detection. ${ }^{14} \mathrm{C}$ activities show a similar variation, with higher activities at TU4 and TU5 (94.5 and $79.2 \mathrm{pMC}$ ) compared to groundwater at TU1 and TU2 (35.4 and $38.0 \mathrm{pMC}$ ). Deeper groundwater at TU3D had lower ${ }^{14} \mathrm{C}$ activities (10.6 pMC). ${ }^{3} \mathrm{H}$ activities in groundwater at Kelly Creek decreased from 0.51 tritium units at $\mathrm{KC} 4$ to 0.40 and 0.36 tritium units at $\mathrm{KC} 1$ and $\mathrm{KC} 2$, respectively. ${ }^{14} \mathrm{C}$ activities follow a similar trend, decreasing from $84.2 \mathrm{pMC}$ at $\mathrm{KC} 4$ to $80.4 \mathrm{pMC}$ at $\mathrm{KC} 1$. 


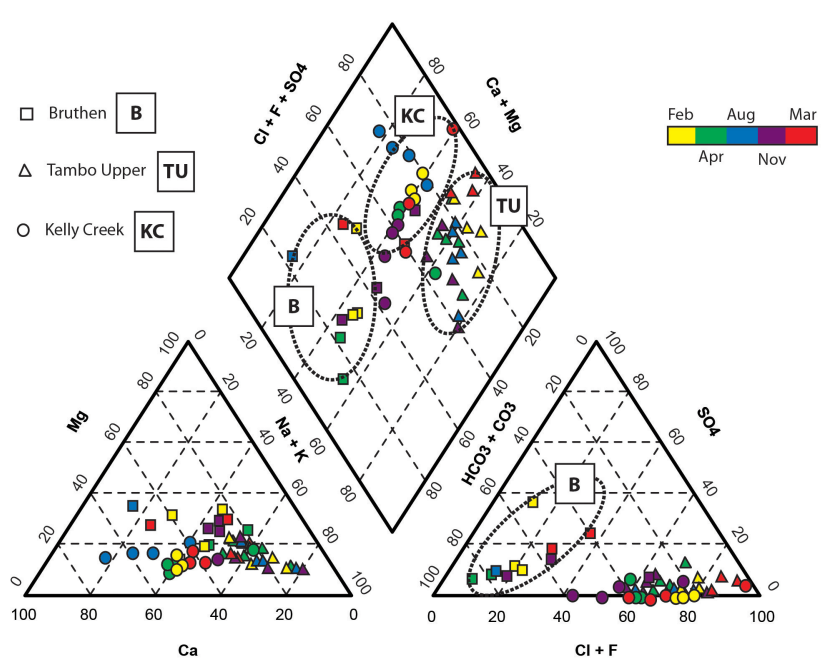

Figure 5. Piper plot of bank water from the Tambo River. Black markers $-\mathrm{HCO}_{3}$ measured; grey and white markers $-\mathrm{HCO}_{3}$ calculated via charge balance.
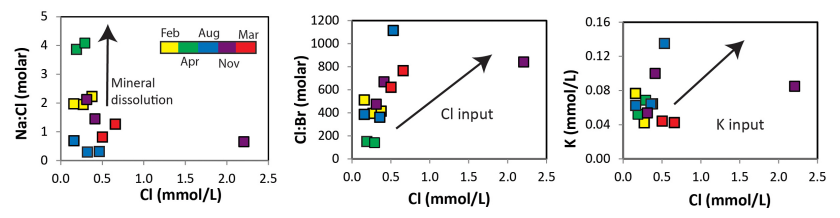

Figure 6. Trends in major ion chemistry at Bruthen indicating mineral dissolution, the input of $\mathrm{Cl}$ into groundwater and the input of $\mathrm{K}$ into groundwater.

\subsection{Major ions}

Despite sampling groundwater from similar aquifers, there are considerable differences in the geochemistry of groundwater from the three locations.

Groundwater from Bruthen is $\mathrm{HCO}_{3}-\mathrm{Ca}-\mathrm{Na}$ type (Fig. 5). $\mathrm{NO}_{3}, \mathrm{Br}$ and $\mathrm{Cl}$ are the most variable anions over time, with relative standard deviations of 120,91 and $82 \%$ of the mean concentrations, respectively. $\mathrm{Na}$ is the most variable cation at the site, with relative standard deviations of $53 \%$ of the mean concentrations. The concentration of most major cations at Bruthen decrease with increasing $\mathrm{Cl}$ concentrations; however $\mathrm{K}$ has a weak positive correlation with $\mathrm{Cl}$ (Fig. 6). Molar $\mathrm{Na}: \mathrm{Cl}$ ratios at Bruthen generally range from 2 to 4 during periods of lower rainfall in the catchment (February 2011, April 2011 and November 2011) and are generally below 1 during periods of increased rainfall (August 2011 and March 2012). Molar $\mathrm{Cl}: \mathrm{Br}$ ratios at Bruthen increase from 140 to over 1000 with increasing $\mathrm{Cl}$ concentrations (Fig. 6).

Groundwater from Tambo Upper is $\mathrm{Cl}-\mathrm{Na}-\mathrm{Ca}$ type (Fig. 5). $\mathrm{NO}_{3}$ is the most temporally variable anion at Tambo Upper, with a relative standard deviation of $97 \%$ of the mean. In contrast, temporal variations in cations are relatively low
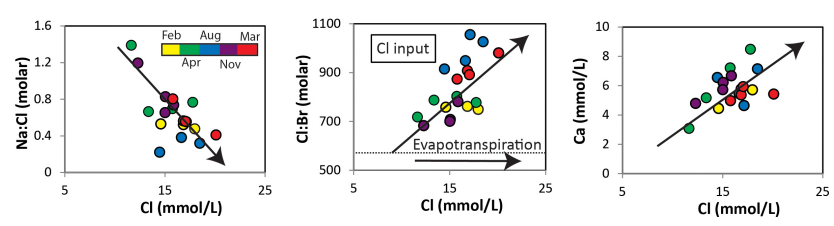

Figure 7. Trends in major ion chemistry at Kelly Creek indicating $\mathrm{Cl}$ inputs during increased rainfall.
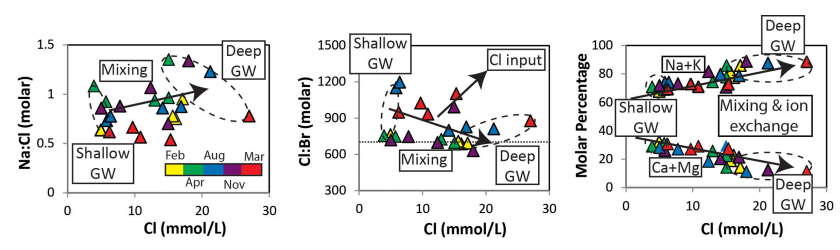

Figure 8. Trends in major ion chemistry at Tambo Upper indicating mixing between groundwater in the shallow, unconfined aquifer and groundwater from the deeper, semi-confined aquifer.

at Tambo Upper, with relative standard deviations of between 15 and $21 \%$ of the mean values. At Tambo Upper $\mathrm{Na}$ and $\mathrm{K}$ concentrations increase and $\mathrm{Ca}$ and $\mathrm{Mg}$ concentrations decrease with increasing $\mathrm{Cl}$ concentrations (Fig. 8). Groundwater further from the river at Tambo Upper (TU4 and TU5) has $\mathrm{Cl}$ concentrations below $10 \mathrm{mmol} \mathrm{L}^{-1}$, $\mathrm{K}$ concentrations below $0.2 \mathrm{mmol} \mathrm{L}^{-1}$ and $\mathrm{Na}$ concentrations below $7 \mathrm{mmol} \mathrm{L}^{-1}$ (Table 1). Deeper groundwater from Tambo Upper (TU3D) has $\mathrm{Cl}$ concentrations greater than $15 \mathrm{mmol} \mathrm{L}^{-1}, \mathrm{~K}$ concentrations greater than $0.8 \mathrm{mmol} \mathrm{L}^{-1}$ and $\mathrm{Na}$ concentrations greater than $16 \mathrm{mmol} \mathrm{L}^{-1}$. Groundwater closer to the river at Tambo Upper (TU1 and TU2) has concentrations of Na, K, $\mathrm{Mg}$ and $\mathrm{Ca}$ that are intermediate between those of groundwater at TU3D and groundwater at TU4 and TU5.

Shallow groundwater at Kelly Creek is $\mathrm{Cl}-\mathrm{Ca}-\mathrm{Na}$ type. $\mathrm{SO}_{4}$ is the most variable anion at Kelly Creek, with relative standard deviations of between 108 and $206 \%$ of mean values at each bore. $\mathrm{Na}$ is the most variable cation at Kelly Creek, with relative standard deviations of between 22 and $43 \%$ of mean values. At Kelly Creek, shallow groundwater has $\mathrm{Cl}$ concentrations that range from 11.6 to $20.1 \mathrm{mmol} \mathrm{L}^{-1}$ and $\mathrm{Ca}$ concentrations that range from 3.1 to $8.5 \mathrm{mmol} \mathrm{L}^{-1}$ (Fig. 7). $\mathrm{Ca}, \mathrm{Na}, \mathrm{K}$ and $\mathrm{Mg}$ concentrations generally increase with $\mathrm{Cl}$ concentrations. Deeper groundwater from Kelly Creek shows similar trends in major ion concentrations to shallower groundwater; however, the relative proportion of $\mathrm{Na}$ and $\mathrm{Mg}$ is higher and the relative proportion of $\mathrm{Ca}$ is lower. Molar $\mathrm{Cl}: \mathrm{Br}$ ratios in groundwater at Kelly Creek increase from $\sim 650$ to $\sim 1000$, while $\mathrm{Na}: \mathrm{Cl}$ ratios decrease from 1.4 to 0.4 as $\mathrm{Cl}$ concentrations increase. 


\section{Discussion}

The following section focusses on identifying the source of water stored in the banks of the Tambo River. Through groundwater dating, the prevalence of bank storage is evaluated and patterns in groundwater recharge and flow are identified. These evaluations are further coupled with major ion and stable isotope analysis under changing hydrological conditions, in order to identify processes controlling the chemistry of bank water and the potential impacts to river and groundwater quality.

\subsection{Hydrogeochemical processes}

$\mathrm{Na}: \mathrm{Cl}$ ratios were higher in the groundwater at Bruthen and Kelly Creek during periods of lower rainfall compared to periods of higher rainfall (Figs. 6 and 7). This suggests that the groundwater present in the banks during periods of low rainfall has longer residence times that facilitate water-rock interaction, specifically the dissolution of Na-bearing minerals such as plagioclase (Edmunds, 2009; Herczeg et al., 2001). The same trend is also apparent in the deeper groundwater at Tambo Upper (Fig. 8). Cl: Br ratios at Bruthen and Kelly Creek increase with increasing $\mathrm{Cl}$ concentrations (Figs. 6 and 7). As evapotranspiration, which is the dominant process that controls groundwater salinity in southeast Australia (Herczeg et al., 2001; Cartwright et al., 2007, 2010), does not impact $\mathrm{Cl}: \mathrm{Br}$ ratios, this implies the addition of $\mathrm{Cl}$ from an external source. Halite dissolution is a potential $\mathrm{Cl}$ source; however, there are no obvious stores of halite in the catchment. An alternative source of $\mathrm{Cl}$ is $\mathrm{KCl}$ fertilisers that are used locally (Department of Environment and Primary Industries, 2013). K: Cl ratios decrease with increasing $\mathrm{Cl}$ concentrations at Bruthen (Fig. 6), which would be not be expected for a $\mathrm{KCl}$ source; however, $\mathrm{K}$ may be removed from waters recharging through the soils by vegetation (e.g. Schachtman and Schroder, 1994) or sorption onto clay minerals such as illite (Griffioen, 2001). In any case, the observation that increased $\mathrm{Cl}$ concentrations coincide with increased rainfall suggests that infiltration facilitates the transport of $\mathrm{Cl}$ from the land surface and/or the soil profile into shallow groundwater (cf. Panno et al., 2006).

Mixing between deeper groundwater (TU3D) and shallow groundwater (TU4) appears to dominate the chemical variability of groundwater throughout the rest of the transect at Tambo Upper (Fig. 8). The deeper groundwater has elevated $\mathrm{Na}: \mathrm{Cl}$ and $\mathrm{K}: \mathrm{Cl}$ ratios, likely to be attributed to greater residence times and $\mathrm{Na}$ and $\mathrm{K}$ mineral dissolution. Deeper groundwater is also relatively saline (17.11 to $27.03 \mathrm{mmol} \mathrm{L}^{-1}$ ) compared to shallower groundwater at TU4 (3.94 to $6.24 \mathrm{mmol} \mathrm{L}^{-1}$ ). Groundwater throughout the rest of the transect contains intermediate $\mathrm{Cl}$ concentrations and cation-to-chloride ratios, which is consistent with mixing between the two endmembers. It is also apparent that the relative proportion of the deeper groundwater endmember in the bank waters at Tambo Upper increases during the wetter periods in August 2011 and March 2012, suggesting that hydraulic loading of the deeper, semi-confined aquifer is driving increased flow of deeper groundwater into the overlying alluvial aquifer at these times. As indicated in Sect. 3.5, high variations in $\mathrm{NO}_{3}$ concentrations were observed both temporally and spatially across the transects. These variations were not systematic with changing hydrological conditions or other major ions, suggesting that perhaps changing redox conditions have impacted the observed $\mathrm{NO}_{3}$ concentrations. However, as redox conditions were not recorded and multispecies analysis of $\mathrm{N}$ were not undertaken, these processes remain unresolved.

\subsection{Aquifer interactions}

The ${ }^{14} \mathrm{C}$ and ${ }^{3} \mathrm{H}$ activities in groundwater may be predicted from their atmospheric concentrations and groundwater residence times. The activities of these isotopes in the atmosphere were elevated due to nuclear tests that occurred mainly in the 1960s (the so-called "bomb pulse"). For this study, present-day ${ }^{3} \mathrm{H}$ activities are taken to be 3.2 tritium units, which is the weighted average rainfall ${ }^{3} \mathrm{H}$ activity for July 2005 to June 2011 in the Melbourne area (Tadros et al., 2014), and we assume that pre-bomb-pulse tritium activities were similar to these (Allison and Hughes, 1977). For intervening years, the mean weighted average of ${ }^{3} \mathrm{H}$ concentration of precipitation in Melbourne was taken as that of local precipitation with the record extrapolated for years with no data (Cartwright et al., 2013). Unlike ${ }^{3} \mathrm{H},{ }^{14} \mathrm{C}$ activities of atmospheric $\mathrm{CO}_{2}$ were similar in the Northern and Southern hemispheres (Fontes, 1983). The data of Hua et al. (2013) were used for ${ }^{14} \mathrm{C}$ activities of precipitation from 1950 to 2011. Pre-1950, ${ }^{14} \mathrm{C}$ activities are assumed to have decreased from $100 \mathrm{pMC}$ in 1905 to $97.5 \mathrm{pMC}$ in 1950 due to fossil fuel burning (Suess, 1971).

Lumped-parameter models are commonly used to describe groundwater flow in shallow unconfined and semi-confined aquifers (Małoszewski and Zuber, 1991, 1982; Morgenstern et al., 2010; Zuber et al., 2005). Piston flow models assume that no mixing takes place between recharge and water in the aquifer and are suitable for settings where dispersion is low. Conversely, exponential flow models assume a vertical stratification of groundwater ages in an aquifer and are suitable for the sampling of fully penetrating wells or surface water bodies fed by aquifers receiving homogeneous recharge. This study uses the exponential piston flow model (EPFM) which combines a portion of piston flow followed by a portion of exponential flow and is appropriate for bores in unconfined to semi-confined aquifers screened below the water table that do not sample the shallowest groundwater that has very short residence times (Morgenstern et al., 2010; Cartwright and Morgenstern, 2012). 


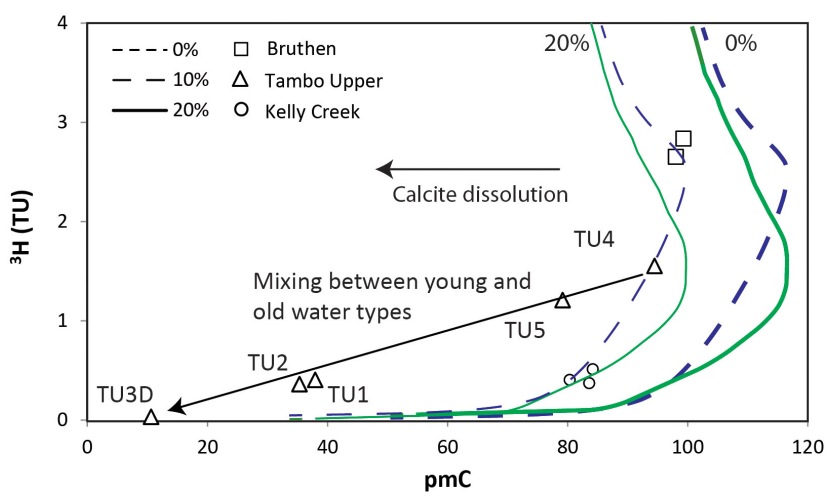

Figure 9. Co-variance of ${ }^{3} \mathrm{H}$ and ${ }^{14} \mathrm{C}$ in groundwater and that predicted by Eq. (1) (solid lines) for 0 and $20 \%$ DIC input from closed-system calcite dissolution. Dashed lines are the predicted covariance of ${ }^{3} \mathrm{H}$ and ${ }^{14} \mathrm{C}$ from the renewal rate model of Le Gal La Salle et al. (2001).

For the EPFM the activity of ${ }^{3} \mathrm{H}$ or ${ }^{14} \mathrm{C}$ at time $t\left(C_{t}\right)$ is given by

$C_{t}=\int_{0}^{\infty} C_{i}(t-\tau) g(\tau) e^{(-\lambda \tau)} \mathrm{d} \tau$,

where $C_{i}$ is the initial ${ }^{3} \mathrm{H}$ or ${ }^{14} \mathrm{C}$ activity, $\lambda$ is the decay constant $\left(5.63 \times 10^{-3} \mathrm{yr}^{-1}\right.$ for ${ }^{3} \mathrm{H}, 1.21 \times 10^{-4} \mathrm{yr}^{-1}$ for $\left.{ }^{14} \mathrm{C}\right), \tau$ is the transit time and $g(\tau)$ is the system response function. The system response function is given by

$g(\tau)=0$ for $\tau<T(1-f)$

and

$g(\tau)=(f T)^{-1} e^{(-\tau /(f t t)+1 / f-1)}$ for $\tau>T(1-f)$,

where $T$ is the mean residence time and $f$ is the ratio of exponential flow to piston flow for the total flow volume ( $\mathrm{Zu}-$ ber et al., 2005). $f$ was estimated at 0.8 for shallow bores neighbouring the Tambo River on the basis of bore depth, screen length and aquifer lithology (cf. Cartwright and Morgenstern, 2012; Cartwright et al., 2013).

While there are some differences in the estimated groundwater residence times between different types of flow models, the predicted variation in ${ }^{14} \mathrm{C}$ and ${ }^{3} \mathrm{H}$ activities are similar in all flow models that involve attenuation of the bombpulse peak of ${ }^{3} \mathrm{H}$ and ${ }^{14} \mathrm{C}$ during flow (e.g. as discussed by Cartwright et al., 2013). A similar covariance of ${ }^{14} \mathrm{C}$ and ${ }^{3} \mathrm{H}$ activities would be obtained using a dispersion model ( $\mathrm{Zu}-$ ber et al., 2005) or the renewal rate model of Le Gal La Salle et al. (2001; Fig. 9). The ${ }^{14} \mathrm{C}$ and ${ }^{3} \mathrm{H}$ activities also constrain mixing within the groundwater system (Le Gal La Salle et al., 2001; Cartwright et al., 2007, 2010, 2013). Mixing between recently recharged groundwater and older groundwater with low ${ }^{14} \mathrm{C}$ and negligible ${ }^{3} \mathrm{H}$ activities will displace water compositions to the left of the predicted ${ }^{14} \mathrm{C}$ vs. ${ }^{3} \mathrm{H}$ trends. Closed-system calcite dissolution that lowers ${ }^{14} \mathrm{C}$ but which does not impact ${ }^{3} \mathrm{H}$ activities produces a similar displacement.

The co-variance between ${ }^{3} \mathrm{H}$ and ${ }^{14} \mathrm{C}$ for groundwater samples is shown in Fig. 9. Groundwater from Bruthen and Kelly Creek has ${ }^{3} \mathrm{H}$ and ${ }^{14} \mathrm{C}$ activities lie close to the predicted co-variance curves. Groundwater in aquifers dominated by siliciclastic sediments typically undergo up to $20 \%$ closed-system calcite dissolution (Vogel, 1970; Clark and Fritz, 1997), and, if that is the case for this groundwater, it would explain the slightly lower than expected ${ }^{14} \mathrm{C}$ activities. Regardless, there can be very limited mixing between older and younger groundwater at these localities. By contrast, groundwater from TU1, TU2 and TU5 at Tambo Upper follow a trend consistent with the mixing between younger groundwater in the shallow aquifer (TU4) and older groundwater in the deeper semi-confined aquifer (TU3D) (Fig. 9). The trend indicates increased leakage from the deeper aquifer into the surface aquifer closer to the river at TU1 and TU2. This is consistent with higher groundwater levels and electrical conductivities at TU1 and TU2 (Fig. 3) that would result from increased connectivity with artesian groundwater in the deeper, semi-confined aquifer. This connection may have resulted from erosion of the clay layers closer to the Tambo River during periodic flooding.

\subsection{Groundwater residence times and mixing}

Groundwater residence times were calculated using the ${ }^{3} \mathrm{H}$ activities and the EPFM with $f=0.8$. Groundwater from Bruthen has relatively short residence times of 2 to 4 years. Groundwater from Kelly Creek has longer residence times (96 to 100 years), which is consistent with the higher degrees of mineral dissolution at Kelly Creek discussed previously. Groundwater from TU4 at Tambo Upper has an intermediate residence time of 27 years. To assess the sensitivity of these results, $f$ values in this study were varied between 0.6 and 1.0. This results in variations of $<0.1$ years at Bruthen and $<15$ years at Kelly Creek. Uncertainties in groundwater age based on the uncertainty of ${ }^{3} \mathrm{H}$ activities were $<1$ year at Bruthen (based on an uncertainty of 0.14 tritium units) and $<1.5$ years at Kelly Creek (based on an uncertainty of 0.04 tritium units). As deeper groundwater from Tambo Upper site is ${ }^{3} \mathrm{H}$-free, residence times were calculated from ${ }^{14} \mathrm{C}$ activities. Making the assumption of $15 \%$ calcite dissolution, age estimates based on Clark and Fritz (1997, their Eq. 2, p. 206) are $\sim 17200$ years.

The relatively young groundwater residence times from the shallow aquifers implies that groundwater recharge in the area is dominantly local, probably within a few hundred metres of the Tambo River. Mean groundwater residence times from the Bruthen bores are similar and within analytical uncertainty, preventing calculation of horizontal flow velocities. Mean groundwater residence times at Kelly Creek 


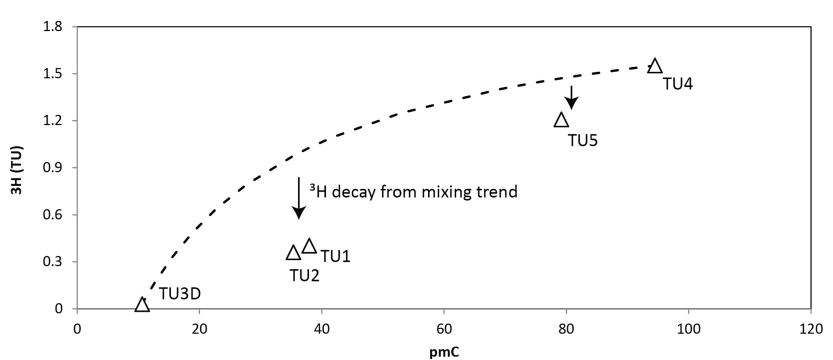

Figure 10. ${ }^{3} \mathrm{H}$ and ${ }^{14} \mathrm{C}$ activities of groundwater at Tambo Upper and predicted trend for mixing between deeper groundwater (TU3D) and shallow groundwater (TU4). Curve based on DIC, ${ }^{3} \mathrm{H}$ and ${ }^{14} \mathrm{C}$ activities from Table 2 .

increase from 96 years at $\mathrm{KC} 4$ to 100 years at $\mathrm{KC} 2$. The age of groundwater at $\mathrm{KC} 1$ is 99 years and within the analytical uncertainty of groundwater at $\mathrm{KC} 2$. Based on these data, groundwater at Kelly Creek has a horizontal flow velocity of between 1.3 and $6.5 \mathrm{~m} \mathrm{year}^{-1}$ towards the river.

The ${ }^{3} \mathrm{H}$ and ${ }^{14} \mathrm{C}$ activities predicted by the mixing between groundwater from TU4 and deeper groundwater are shown in Fig. 10. While it is possible that groundwater from TU4 has already undergone some mixing with deeper groundwater (and $\mathrm{C}$ inputs from the aquifer are less than $10 \%$ opposed to the $10-20 \%$ indicated), this remains difficult to define. As such, mixing estimates at Tambo Upper will be conservative with respect to the input of deeper groundwater. Groundwater from TU1, TU2 and TU5 plot below the mixing trend in Fig. 10. While there are uncertainties in these calculations, it is possible that ${ }^{3} \mathrm{H}$ activities are lower than expected due to the decay of ${ }^{3} \mathrm{H}$ in shallow groundwater. Exponential piston flow modelling of water at TU1 and TU2 indicates that a residence time of $\sim 20$ years would be required to cause the observed deviation in ${ }^{3} \mathrm{H}$ activities from the mixing trend shown in Fig. 10. This suggests a horizontal flow rate of $1.8 \pm 0.6 \mathrm{~m}_{\text {year }}{ }^{-1}$ towards the Tambo River at the Tambo Upper transect. This is consistent with shallow groundwater recharge on the floodplains of the Tambo River and groundwater flow towards the river, which is expected given the gaining nature of this section of the river (Unland et al., 2013).

\subsection{Implications for groundwater-surface water interaction}

The distribution of groundwater residence times does not support increased bank storage in the area immediately (within tens of metres) neighbouring the Tambo River. If this were so, groundwater closer to the Tambo River would contain a higher proportion of younger water than groundwater further from the river and groundwater ages would decline towards the river. Instead, groundwater ages increase towards the Tambo River at Kelly Creek and Tambo Upper, while
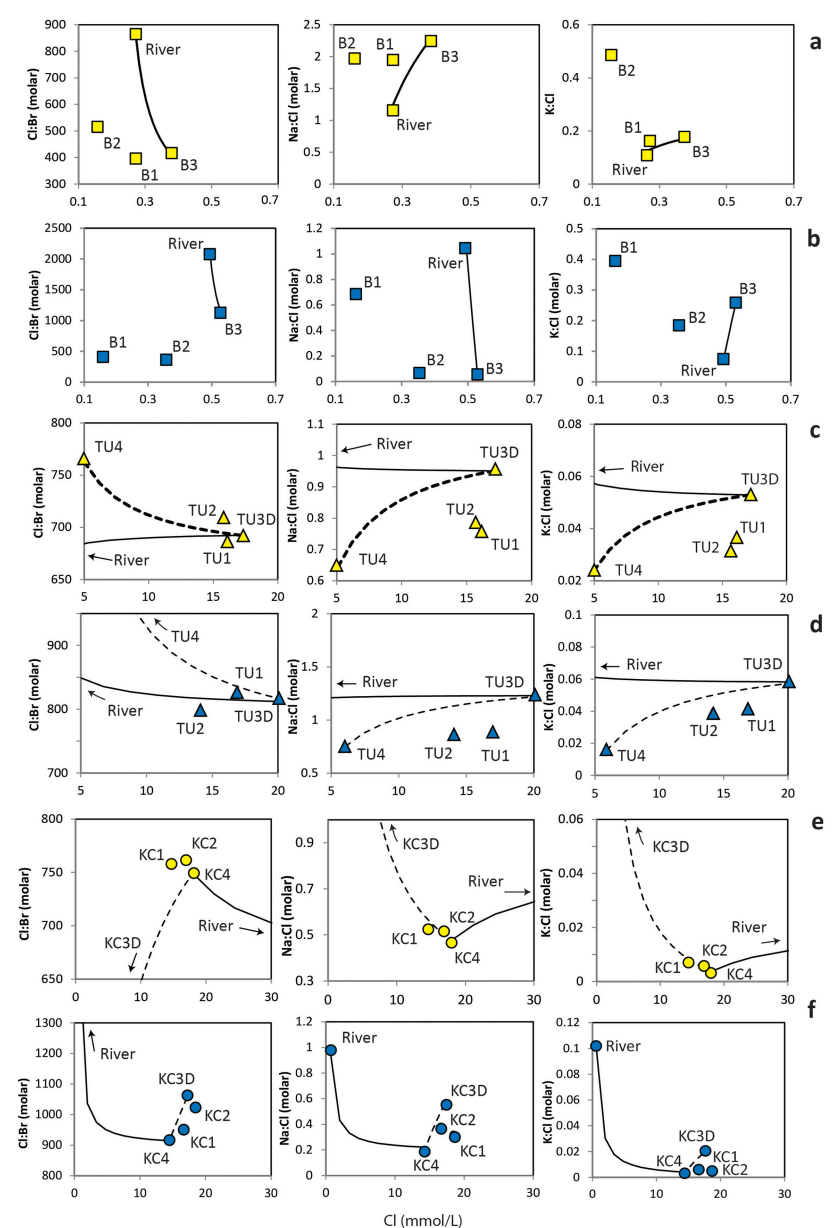

Figure 11. Predicted mixing curves between river water and groundwater at Bruthen (a, b), Tambo Upper (c, d) and Kelly Creek $(\mathbf{e}, \mathbf{f})$ constructed using the endmember compositions from Tables 1 to 3. Yellow data points - February 2011; blue data points - August 2011.

groundwater a Bruthen was approximately the same age at 18 and $6 \mathrm{~m}$ distance from the Tambo River.

As the ${ }^{3} \mathrm{H}$ and ${ }^{14} \mathrm{C}$ activities were analysed for groundwater sampled in April 2011, these data can only be used to evaluate bank storage for the hydrological conditions at and immediately prior to sampling. This included a discharge event that increased river height by $0.5 \mathrm{~m}$ approximately 2 weeks prior to sampling. As such, these data indicate that an increase in river height of $0.5 \mathrm{~m}$ is not large enough to produce bank storage 5 to $10 \mathrm{~m}$ distance from of the river for a period greater than 2 weeks. Major ions and stable isotopes were analysed several times, including after flood events which increased river height by $\sim 5 \mathrm{~m}$. Again there is little evidence of river water infiltrating into the river banks following these events. The curves expected for the mixing between shallow groundwater furthest from the river, deeper groundwater and river water at each transect with respect to $\mathrm{Cl}: \mathrm{Br}, \mathrm{Na}: \mathrm{Cl}$ and $\mathrm{K}: \mathrm{Cl}$ ratios are shown in Fig. 11. 
Data are shown for February 2011 and August 2011 to represent baseflow conditions, when bank infiltration is likely to have the least impact on groundwater chemistry, and postflood conditions, when bank infiltration is most likely to impact groundwater chemistry.

The composition of groundwater from the two bores closest to the Tambo River at each transect are not consistent with the trends expected for mixing between river water and deeper or shallow groundwater further form the river. For example, during both February and August at Bruthen, $\mathrm{Cl}: \mathrm{Br}$, $\mathrm{Na}: \mathrm{Cl}$ and $\mathrm{K}: \mathrm{Cl}$ ratios from groundwater at $\mathrm{B} 1$ and $\mathrm{B} 2$ plot to the left the curves expected for mixing between river water and groundwater further from the river at B3 (Fig. 11a and $\mathrm{b}$ ). This is partly due to the higher $\mathrm{Cl}$ concentrations in river water and groundwater from B3 (which range from 0.3 to $0.5 \mathrm{mmol} \mathrm{L}^{-1}$ ) compared to groundwater from $\mathrm{B} 1$ and $\mathrm{B} 2$ (which range from 0.1 to $0.35 \mathrm{mmol} \mathrm{L}^{-1}$ ). If mixing between river water and groundwater at $\mathrm{B} 3$ were occurring, $\mathrm{Cl}$ concentrations at $\mathrm{B} 1$ and $\mathrm{B} 2$ would be intermediate between those in the river and at B3.

The same is true at Tambo Upper, where $\mathrm{Cl}$ concentrations in groundwater at TU1 and TU2 are higher $\left(\sim 15 \mathrm{mmol} \mathrm{L}^{-1}\right)$ than in river water or groundwater further from the river at TU4 $\left(<10 \mathrm{mmol} \mathrm{L}^{-1}\right)$ during both baseflow and flood conditions (Fig. 11c and d). The same is true for EC values which are lower in river water and at TU4 (ranging from 120 to $881 \mu \mathrm{S} \mathrm{cm}^{-1}$ over the study) compared to EC values at TU1 and TU2, which ranged from 1350 to $2682 \mu \mathrm{S} \mathrm{cm}^{-1}$ over the study. Again, if mixing between river water and water at TU4 had a significant impact on groundwater chemistry at TU1 and TU2, Cl concentrations and EC values would be expected to be intermediate between the river water and groundwater from TU4. Instead, groundwater in TU1 and TU2 has a geochemistry that is similar to that which would be expected for mixing between TU4 and TU3D (Fig. 11c and d). As asserted in Sect. 4.1, such mixing is implied by the ${ }^{3} \mathrm{H}$ and ${ }^{14} \mathrm{C}$ data. Similarly, $\delta^{2} \mathrm{H}$ and $\delta^{18} \mathrm{O}$ values of groundwater close to the Tambo River do not decline after significant flooding, as would be expected for the infiltration of river water with the lower $\delta^{2} \mathrm{H}$ and $\delta^{18} \mathrm{O}$ values observed during flooding.

These observations indicate that river water penetrates $<5 \mathrm{~m}$ into the banks during flooding, suggesting limited bank infiltration. The absence of significant bank infiltration is consistent with results of Vekerdy and Meijerink (1998) and Wett et al. (2002), who found bank infiltration to be minimal in confined and semi-confined aquifers, where pressure loading from the flood wave propagated rapidly into the neighbouring aquifers, limiting bank infiltration. While most bores near the Tambo River are screened in the alluvial aquifer which is unconfined, leakage of the underlying semiconfined aquifer into the alluvial aquifer does occur (Fig. 9). This upward leakage occurs close rivers where erosion has removed some of the confining layers (Rinaldi and Darby, 2007). It is possible that bank storage is occurring but that

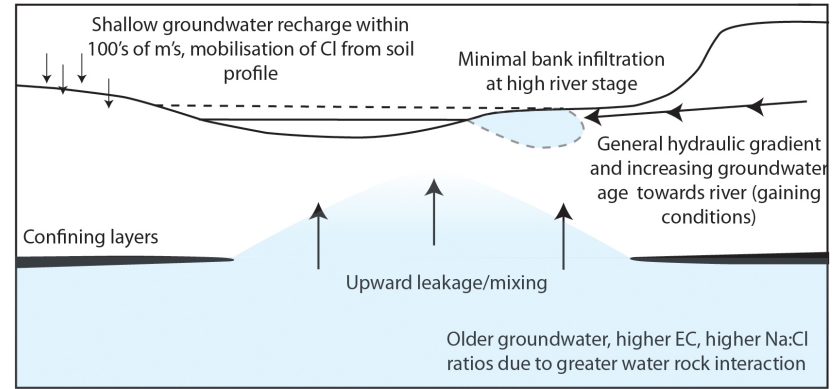

Figure 12. Schematic representation of the Tambo River and major hydrogeochemical processes at baseflow (solid line) and high-flow (dashed line) conditions. The deeper groundwater is from 15 to $20 \mathrm{~m}$ below ground surface within the alluvial aquifer and is confined beneath the clay layer.

the gaining nature of the Tambo River near these transects is driving the return of bank water back into the river before sampling has taken place (Fig. 12). If this is the case, the storage period ( $\sim 1$ week after the flood peak) is significantly shorter than the several weeks to months predicted by modelling (e.g. Cooper and Rorabaugh, 1963; Doble et al., 2012; McCallum et al., 2010; Whiting and Pomeranets, 1997). It is likely that the apparent absence of bank storage near the Tambo River is being driven by a combination of such factors, including (1) upward flow of groundwater from the deeper aquifer into the river bank due to pressure loading on the floodplain; (2) the return of any bank waters back into the river under strongly gaining conditions; and (3) the highTDS (total dissolved solids) water from the confined system masking the chemical impact of infiltrating river water.

\section{Conclusions}

This study was able to determine the absence of significant bank storage near the Tambo River by dating near-river groundwater and characterising its major ion chemistry before and after flooding. The combined use of ${ }^{3} \mathrm{H}$ and ${ }^{14} \mathrm{C}$ activities indicate that recharge in the alluvial aquifer is dominantly local (within hundreds of metres of the Tambo River). The covariance between ${ }^{3} \mathrm{H}$ and ${ }^{14} \mathrm{C}$ activities show that mixing between relatively old groundwater from a deeper semiconfined aquifer and younger groundwater from the unconfined alluvial aquifer is occurring in parts of the Tambo River bank. It is further shown that, by coupling ${ }^{3} \mathrm{H}$ and ${ }^{14} \mathrm{C}$ to define a mixing trend, deviations in the activity of ${ }^{3} \mathrm{H}$ from the trend can be used to estimate the likely age of groundwater along its flow path. $\mathrm{Na}: \mathrm{Cl}$ ratios $>1$ in groundwater sampled during baseflow conditions and in older groundwater from the area indicate the dissolution of Na-bearing minerals and are consistent with the weathering of silicic sands in the aquifer. Increasing $\mathrm{Cl}: \mathrm{Br}$ ratios and increasing $\mathrm{Cl}$ concentrations during periods of increased rainfall indicate an input of 
$\mathrm{Cl}$, which is consistent with the mobilisation of $\mathrm{Cl}$ accumulated in the soil profile through the use of fertilisers. Increasing groundwater age with proximity to the Tambo River is consistent with the gaining nature of the Tambo River but does not suggest that exchange between groundwater and surface water increases with increasing proximity to the river. Major ions, $\delta^{2} \mathrm{H}$ and $\delta^{18} \mathrm{O}$ values support this and do not show trends consistent with an increased input of river water to the groundwater closer to the river. These results suggest either that the strongly gaining nature of the Tambo River at the study locations is preventing significant lateral infiltration of river water into the bank or that the rapid propagation of pressure into the underlying semi-confined aquifer, followed by leakage into the above unconfined aquifer is preventing significant bank infiltration.

These results are indicative of the highly complex nature of groundwater and surface water processes that may be occurring within river banks and illustrates that, while models can significantly help in conceptualising our understanding of groundwater-surface water interactions, field studies can offer complementary information that may otherwise be overlooked. In this setting, the assumption of typical bank storage processes and the use of a regional groundwater endmember during mass balance calculations would lead to poor groundwater flux estimates. In this context, the importance of nested piezometers near rivers to more accurately characterise near-river groundwater processes has been highlighted. Even the monitoring of relatively inexpensive parameters such as groundwater levels, EC and $\mathrm{Cl}$ can provide significant information to researchers and groundwater managers when conducting such studies.

Acknowledgements. The authors thank Massimo Raveggi and Rachelle Pierson for their help with major ion analyses. ${ }^{3} \mathrm{H}$ and ${ }^{14} \mathrm{C}$ analysis at ANSTO was conducted with the help of AINSE funding. Further funding for this research was provided by the National Centre for Groundwater Research and Training, an Australian Government initiative, supported by the Australian Research Council and the National Water Commission.

Edited by: M. Giudici

\section{References}

Allison, G. B. and Hughes, M. W.: The history of tritium fallout in southern Australia inferred from rainfall and wine samples, Earth Planet. Sci. Lett., 36, 334-340, 1977.

Atkinson, A. P., Cartwirght, I., Gilfedder, B. S., Hofmann, H., Unland, N. P., Cendón, D. I., and Chisari, R.: A multi-tracer approach to quantifying groundwater inflows to an upland river; assessing the influence of variable groundwater chemistry, Hydrol. Process., doi:10.1002/hyp.10122, in press, 2013.

Birch, W. D.: The Geology of Victoria. Geological Society of Australia (Victorian Division), Sydney, 2003.
Boulton, A. J.: Stream ecology and surface-hyporheic hydrologic exchange: Implications, techniques and limitations, Mar. Freshw. Res., 44, 553-564, 1993.

Boulton, A. J.: Chances and challenges in the conservation of groundwaters and their dependent ecosystems. Aquatic Conservation, Mar. Freshw. Ecosyst., 15, 319-323, 2005.

Bourg, A. C. M. and Bertin, C.: Biogeochemical processes during the infiltration of river water into an alluvial aquifer, Environ. Sci. Technol., 27, 661-666, 1993.

Bureau of Meteorology: Commonwealth of Australia, Bureau of Meteorology, available at: http://www.bom.gov.au, last access: 28 August 2013.

Cartwright, I. and Morgenstern, U.: Constraining groundwater recharge and the rate of geochemical processes using tritium and major ion geochemistry: Ovens catchment, southeast Australia, J. Hydrol., 475, 137-149, 2012.

Cartwright, I., Weaver, T. R., Stone, D., and Reid, M.: Constraining modern and historical recharge from bore hydrographs, ${ }^{3} \mathrm{H}$, ${ }^{14} \mathrm{C}$, and chloride concentrations: Applications to dual-porosity aquifers in dryland salinity areas, Murray Basin, Australia, J. Hydrol., 332, 69-92, 2007.

Cartwright, I., Weaver, T. R., Simmons, C. T., Fifield, L. K., Lawrence, C. R., and Chisari, R.: Physical hydrogeology and environmental isotopes to constrain the age, origins, and stability of a low-salinity groundwater lens formed by periodic river recharge: Murray Basin, Australia, J. Hydrol., 380, 203-221, 2010.

Cartwright, I., Fifield, L. K., and Morgenstern, U.: Using ${ }^{3} \mathrm{H}$ and ${ }^{14} \mathrm{C}$ to constrain the degree of closed-system dissolution of calcite in groundwater, Appl. Geochem., 32, 118-128, 2013.

Cartwright, I., Gilfedder, B., and Hofmann, H.: Contrasts between estimates of baseflow help discern multiple sources of water contributing to rivers, Hydrol. Earth Syst. Sci., 18, 15-30, doi:10.5194/hess-18-15-2014, 2014.

Cendón, D. I., Larsen, J. R., Jones, B. G., Nanson, G. C., Rickleman, D., Hankin, S. I., Pueyo, J. J., and Maroulis, J.: Freshwater recharge into a shallow saline groundwater system, Cooper Creek floodplain, Queensland, Australia, J. Hydrol., 392, 150163, 2010.

Cey, E. E., Rudolph, D. L., Aravena, R., and Parkin, G.: Role of the riparian zone in controlling the distribution and fate of agricultural nitrogen near a small stream in southern Ontario, J. Contamin. Hydrol., 37, 45-67, 1999.

Chen, $X$. and Chen, X.: Stream water infiltration, bank storage, and storage zone changes due to stream-stage fluctuations, J. Hydrol., 280, 246-264, 2003.

Chen, X., Chen, D. Y., and Chen, X.-H.: Simulation of baseflow accounting for the effect of bank storage and its implication in baseflow separation, J. Hydrol., 327, 539-549, 2006.

Clark, I. D. and Fritz, P.: Environmental Isotopes in Hydrogeology, Lewis, New York, USA, 206 pp., 1997.

Cooper, H. H. and Rorabaugh, M. I.: Ground-water movements and bank storage due to flood stages in surface streams, United States Department of the Interior, Geological Survey Water-Supply Paper, Washington, 1963.

Coplen, T. B.: Normalisation of oxygen and hydrogen isotope data, Chem. Geol.: Isotope Geoscience section, 72, 293-297, 1988. 
Department of Agriculture, Fisheries and Forestry: Gippsland Catchment, available at: http://adl.brs.gov.au/water2010/pdf/ catchment2230summary.pdf (last access: 19 November 2012), 2006.

Department of Environment and Primary Industries: Victorian Resources Online, Groundwater, available at: http://vro.dpi.vic.gov. $\mathrm{au} / \mathrm{dpi} / \mathrm{vro} / \mathrm{vrosite} . n s f /$ pages/water-gw-quality-quantity, last access: 5 July 2013.

Doble, R., Brunner, P., McCallum, J., and Cook, P. G.: An analysis of river bank slope and unsaturated flow effects on bank storage, Ground Water, 50, 77-86, 2012.

Edmunds, W. M.: Geochemistry's vital contribution to solving water resource problems, Appl. Geochem., 24, 1058-14073, 2009.

Fetter, C. W.: Applied hydrogeology, Merrill, New Jersey, 1994.

Fink, D., Hotchkis, M., Hua, Q., Jacbosen, G., Smith, A. M., Zoppi, U., Child, D., Mifsud, C., Vender Gaast, H., Williams, A., and Williams, M.: The Antares AMS facility at ANSTO, Nuclear Instrum. Methods Phys. Res., 223, 109-115, 2004.

Fontes, J.-Ch.: Dating of Groundwater. Guidebook on Nuclear Techniques in Hydrology, Technical Reports Series No. 91, IAEA, Vienna, 285-317, 1983.

Fukada, T., Hiscock, K. M., Dennis, P. F., and Grischek, T.: A dual isotope approach to identify denitrification in groundwater at a river-bank infiltration site, Water Res., 37, 3070-3078, 2003.

Griffioen, J.: Potassium adsorption ratios as an indicator for the fate of agricultural potassium in groundwater, J. Hydrol., 254, 244 254, 2001.

Herczeg, A. L., Dogramaci, S. S., and Leany, F. W.: Origin of dissolved salts in a large, semi-arid groundwater system: Murray Basin, Australia, Mar. Freshw. Res., 52, 41-52, 2001.

Hiscock, K. M. and Grischek, T.: Attenuation of groundwater pollution by bank filtration, J. Hydrol., 266, 139-144, 2002.

Hocking, J. B.: Definition and revision of Tertiary stratigraphic units, onshore Gippsland Basin, Geological Survey of Victoria, Department of minerals and energy, Victoria, 1976.

Hofmann, H. and Cartwright, I.: Using hydrogeochemistry to understand inter-aquifer mixing in the on-shore part of the Gippsland Basin, southeast Australia, Appl. Geochem., 33, 84-103, 2013.

Hua, Q., Barbetti, M., and Rakowski, A. Z.: Atmospheric Radiocarbon for the period 1950-2010, Radiocarbon, 55, 2059-2072, 2013.

Hughes, C. E. and Crawford, J.: A new precipitation weighted method for determining the meteoric water line for hydrological applications demonstrated using Australian and global GNIP data, J. Hydrol., 464-465, 344-351, 2012.

Lambs, L.: Interactions between groundwater and surface water at river banks and the confluence of rivers, J. Hydrol., 288, 312326, 2004.

Lamontagne, S., Leaney, F. W., and Herczeg, A. L.: Groundwatersurface water interactions in a large semi-arid floodplain: implications for salinity management, Hydrol. Process., 19, 30633080, 2005.

Lamontagne, S., Taylor, A. R., Cook, P. G., and Barrett, C.: Interconnection of Groundwater Systems - River Losses from Losing/Disconnected Streams. Gwydir River Site Report. CSIRO: Water for a Healthy Country National Research Flagship, available at: http://www.clw.csiro.au/publications/waterforahealthycountry/ 2011/wfhc-interconnection-Gwydir-River.pdf, 2011.

Le Gal La Salle, C., Marlin, C., Leduc, C., Taupin, J. D., Massault, M., and Favreau, G.: Renewal rate estimation of groundwater based on radioactive tracers $\left({ }^{3} \mathrm{H},{ }^{14} \mathrm{C}\right)$ in an unconfined aquifer in a semi-arid area, Iullemeden Basin, Niger, J. Hydrol., 254, 145-156, 2001.

Leonard, J. G.: An overview of Victoria's groundwater resources. Background report S3, short term planning guidelines. Drought management plan for Victoria's water resources, Department of Water Resources, Melbourne, Victoria, 1992.

Małoszewski, P. and Zuber, A.: Determining the turnover time of groundwater systems with the aid of environmental tracers: 1. Models and their applicability, J. Hydrol., 57, 207-231, 1982.

Małoszewski, P. and Zuber, A.: Influence of Matrix Diffusion and Exchange Reactions on Radiocarbon Ages in Fissured Carbonate Aquifers, Water Resour. Res., 27, 1937-1945, 1991.

McCallum, J. L., Cook, P. G., Brunner, P., and Berhane, D.: Solute dynamics during bank storage flows and implications for chemical base flow separation, Water Resour. Res., 46, W07541, doi:10.1029/2009WR008539, 2010.

Morgenstern, U. and Taylor, C. B.: Ultra low-level tritium measurement using electrolytic enrichment and LSC, Isotopes Environ. Health, 45, 96-117, 2009.

Morgenstern, U., Stewart, M. K., and Stenger, R.: Dating of streamwater using tritium in a post nuclear bomb pulse world: continuous variation of mean transit time with streamflow, Hydrol. Earth Syst. Sci., 14, 2289-2301, doi:10.5194/hess-14-22892010, 2010.

Panno, S. V., Hackley, K. C., Hwang, H. H., Greenberg, S. E., Krapac, I. G., Landsberger, S., and O'Kelly, D. J.: Source identification of sodium and chloride in natural waters: Preliminary results, Ground Water, 44, 176-187, 2006.

Pinder, G. F. and Sauer, S. P.: Numerical simulation of flood wave modification due to bank storage effects, Water Resour.Res., 7, 63-70, 1971.

Rinaldi, M. and Darby, S. E.: 9 Modelling river-bank-erosion processes and mass failure mechanisms: progress towards fully coupled simulations, Develop. Earth Surf. Proc., 11, 213-239, 2007.

Schachtman, D. P. and Schroeder, J. I.: Structure and transport mechanism of a high-affinity potassium uptake transporter from higher plants, Nature, 370, 655-658, 1994.

Singh, K. P.: Some Factors Affecting Baseflow, Water Resour. Res., 4, 985-999, 1968.

Southern Rural Water. Gippsland Groundwater Atlas, available at: http://www.srw.com.au/gippsland (last access: 25 June 2014), 2013

Stuiver, M. and Polach, H. A.: Reporting of ${ }^{14} \mathrm{C}$ data, Radiocarbon, 19, 355-363, 1977.

Suess, H.: Climatic changes and atmospheric radiocarbon, Palaeogeogr. Palaeocli. Palaeoecol., 10, 199-202, 1971.

Tadros, C. V., Hughes, C. E., Crawford, J. C., Hollins, S. E., and Chisari, R.: Tritium in Australian precipitation: a 50 year record, J. Hydrol., 513, 262-273, 2014.

Tóth, J.: A theoretical analysis of groundwater flow in small drainage basins, J. Geophys. Res., 68, 4795-4812, 1963. 
Unland, N. P., Cartwright, I., Andersen, M. S., Rau, G. C., Reed, J., Gilfedder, B. S., Atkinson, A. P., and Hofmann, H.: Investigating the spatio-temporal variability in groundwater and surface water interactions: a multi-technique approach, Hydrol. Earth Syst. Sci., 17, 3437-3453, doi:10.5194/hess-17-3437-2013, 2013.

Vekerdy, Z. and Meijerink, A. M. J.: Statistical and analytical study of the propagation of flood-induced groundwater rise in an alluvial aquifer, J. Hydrol., 205, 112-125, 1998.

Victorian Water Resources Data Warehouse, available at: http:// www.vicwaterdata.net/vicwaterdata/home.aspx, last access: 28 August 2013.

Vogel, J. C.: Groningen radiocarbon dates IX, Radiocarbon, 12, 444-471, 1970.

Wett, B., Jarosch, H., and Ingerle, K.: Flood induced infiltration affecting a bank filtrate well at the River Enns, Austria, J. Hydrol., 266, 222-234, 2002.
Whiting, P. J. and Pomeranets, M.: A numerical study of bank storage and its contribution to streamflow, J. Hydrol., 202, 121-136, 1997.

Winter, T. C., Harvey, J. W., Franke, O. L., and Alley, W. M.: Ground water and surface water a single resource, US Geological Survey Circuar, Denver, Colorado, 1998.

Woessner, W. W.: Stream and fluvial plain ground water interactions: Rescaling hydrogeologic thought, Ground Water, 38, 423 429, 2000.

Zuber, A., Witczak, S., Rozaski, K., liwka, I., Opoka, M., Mochalski, P., Kuc, T., Karlikowska, J., Kania, J., Jackowicz-Korczyski, and Duliski, M.: Groundwater dating with ${ }^{3} \mathrm{H}$ and $\mathrm{SF}_{6}$ in relation to mixing patterns, transport modelling and hydrochemistry, Hydrol. Process., 19, 2247-2275, 2005. 